\author{
Przemysław Kędzierskia)*, M.Sc.Eng., Adam Szopa, M.Sc.Eng. ${ }^{a)}$ \\ a) Główny Instytut Górnictwa / Central Mining Institute \\ *Autor korespondencyjny / Corresponding author: pkedzierski@gig.katowice.pl
}

\title{
The Electrostatic Properties of Plastic Pipes in relation to Ignition Risk - Testing, Assessment and Elimination
}

\author{
Właściwości elektrostatyczne rur z tworzyw sztucznych w aspekcie zagrożenia wybuchem \\ - badania, ocena i eliminacja
}

\author{
Электростатические свойства пластиковых труб с точки зрения угрозы взрыва \\ - исследования, оценки и устранение угроз
}

\begin{abstract}
Aim: The article describes methods for eliminating the risk of an electrostatic discharge formation which could initiate an explosive atmosphere conflagration.

Introduction: An explosive atmosphere, according to Directive 2014/34/EU, is defined as a mixture with air, under atmospheric conditions, of flammable substances in the form of gases, vapours, mists or dusts, in which combustion spreads to the entire unburned mixture after ignition. Electrostatic discharge is considered a process of rapid electrification decay, accompanied by a release of energy, together with light and acoustic effects.

Project and methods: A resistance measurement result and/or a resistivity parameter, determined on the basis of the measured resistance, were used to determine the electrostatic properties of materials, i.e. to classify them as conductive, dissipative or insulating. The electrification ability test (also called "the electrification test") was performed to determine whether a non-conductive material can charge up to a degree sufficient to result in a brush discharge, and thus become an explosive mixture-ignition source. Electrostatic brush discharges are discharges from small areas (the literature and standards consider a $100 \mathrm{~cm}^{2}$ area to be an effective surface area). Each pipe was tested at no further than one metre from the mouth of the pipe. Information regarding the magnitude of the electrostatic charge, e.g. in the middle of the pipe, was not available.

Results: Based on the performed tests, it can be concluded that:

1. A polyethylene pipe is an electrostatic insulator with very good electrification and surplus electric charge accumulation abilities.

2. The pipe is not able to carry a charge to the ground when in contact with the ground.

3. The entire metal structure is conductive and connected to the ground, so it cannot be electrified by induction.

4. Due to their connection to the studied construction, metal signal wires inserted into the plastic pipes constitute a grounded object with an electric potential equal to zero; therefore, a discharge to the metal wire is very likely.

5. A polyethylene pipe with a very large inner surface has many effective $100 \mathrm{~cm}^{2}$ areas from which the gathered electrostatic charge can initiate a sparkover.

Conclusions: The conclusions in this paper shown actions needed to eliminate electrostatic discharges and ignition possibilities. The proposed preventive measures should be classified into the following groups:

- removing discharge sources in the form of electrostatic charges,

- eliminating potentially explosive atmospheres,

- preventing the possibility of electrostatic discharge formation.

Keywords: static electricity, pipes, explosive atmosphere, electrification ability

Type of article: original scientific article
\end{abstract}

Received: 18.01.2016; Reviewed: 18.03.2017; Published: 31.03.2017;

Percentage contribution: P. Kędzierski - 70\%, A. Szopa - 30\%;

Please cite as: BiTP Vol. 45 Issue 1, 2017, pp. 14-25, doi: 10.12845/bitp.45.1.2017.1;

This is an open access article under the CC BY-NC-SA 4.0 license (https://creativecommons.org/licenses/by-nc-sa/4.0/).

\section{ABSTRAKT}

Cel: W artykule opisano metody eliminacji zagrożenia wyładowaniem elektrostatycznym, mogącym zainicjować wybuch atmosfery wybuchowej. Wprowadzenie: Atmosfera wybuchowa, według dyrektywy 2014/34/EU, jest definiowana jako mieszanina substancji palnych w postaci gazów, par, mgieł lub pyłów z powietrzem w warunkach atmosferycznych, w której zapłon powoduje rozprzestrzenienie się spalania na całą niespaloną mieszaninę. Wyładowanie elektrostatyczne traktowane jest jako proces gwałtownego zaniku stanu naelektryzowania, któremu towarzyszy wydzielenie energii wraz z efektami świetlnymi i akustycznymi. 
Projekt i metody: Do określenia właściwości elektrostatycznych materiałów, czyli zakwalifikowania materiału jako przewodzącego, rozpraszającego lub izolatora, wykorzystywano wynik pomiaru rezystancji i/lub parametr rezystywności, wyznaczony na podstawie zmierzonej rezystancji. Przeprowadzono badanie zdolności do elektryzacji (zwane badaniem elektryzacji) będące metodą pozwalającą określić, czy materiał nieprzewodzący może naładować się w stopniu wystarczającym do tworzenia wyładowań o charakterze snopiastym i przez to stać się źródłem zapłonu mieszaniny wybuchowej. Wyładowania elektrostatyczne snopiaste są wyładowaniami z małych powierzchni (literatura i normy podają za efektywną powierzchnię o polu 100 cm²). Rury każdorazowo badano w odległości wynoszącej maksymalnie metr od ich początku. Nie zdefiniowano wielkości ładunku elektrostatycznego np. w połowie długości rury. Wyniki: Na podstawie przeprowadzonych badań ustalono, że:

1. Rura z polietylenu jest izolatorem elektrostatycznym oraz posiada bardzo dobrą zdolność do elektryzacji i gromadzenia nadmiarowego ładunku elektrycznego.

2. W przypadku kontaktu z uziemieniem odprowadzenie ładunku z rury nie jest możliwe,

3. Cała konstrukcja metalowa jest przewodząca i połączona z uziemieniem, wobec czego nie jest w stanie naelektryzować się poprzez indukcję.

4. Druty metalowe sygnałowe wprowadzane do rur z tworzywa, poprzez połączenie z badaną konstrukcją, stanowią obiekt uziemiony o potencjale elektrycznym równym zero, wobec czego wyładowanie elektrostatyczne do metalowego drutu jest bardzo prawdopodobne.

5. Rura z polietylenu o bardzo dużej powierzchni wewnętrznej posiada wiele powierzchni efektywnych o powierzchni $100 \mathrm{~cm}{ }^{2}$, z których zgromadzony tadunek elektrostatyczny może zainicjować przeskok iskry.

Wnioski: Wnioski przedstawione w artykule pozwalają określić działania mające na celu wyeliminowanie ryzyka wyładowania elektrostatycznego i zapłonu. Zaproponowane środki zaradcze sklasyfikowano w trzech grupach:

- usuwanie ładunku elektrostatycznego jako źródła wyładowania,

- usuwanie atmosfery potencjalnie wybuchowej,

- niedoprowadzanie do możliwości powstania wyładowania elektrostatycznego.

Słowa kluczowe: elektryczność statyczna, rury, atmosfera wybuchowa, zdolność do elektryzacji

Typ artykułu: oryginalny artykuł naukowy

Przyjęty: 18.01.2016; Zrecenzowany: 18.03.2017; Opublikowany: 31.03.2017;

Procentowy wkład merytoryczny: P. Kędzierski - 70\%, A. Szopa - 30\%;

Proszę cytować: BiTP Vol. 45 Issue 1, 2017, pp. 14-25, doi: 10.12845/bitp.45.1.2017.1;

Artykuł udostępniany na licencji CC BY-NC-SA 4.0 (https://creativecommons.org/licenses/by-nc-sa/4.0/).

\section{АННОТАЦИЯ}

Цель: В статье описан способ устранения риска образования электростатического разряда, который может инициировать взрыв во взрывоопасной атмосфере.

Введение: Взрывоопасная атмосфера, в соответствии с директивой 2014/34/ЕС, определяется как смесь легко воспламеняющихся веществ в виде газов, пара, тумана или пыли с воздухом в атмосферных условиях, в которых, при воспламенении горение распространяется на всю несгоревшую смесь. Электростатический разряд считается как процесс быстрого исчезновения состояния наэлектризованности, сопровождаемого выделением энергии наряду со световыми и акустическими эффектами.

Проект и методы: Для того чтобы определить электростатические свойства материалов, которые квалифицируют материал в качестве проводящего, рассеивающего или изолирующего, был использован результат измерения сопротивления и/или параметра удельного сопротивления определенного на основании измерения сопротивления. Проведен анализ на электризацию (называемое тестированием электризации), который представляет собой способ определения возможности непроводящего материала зарядиться до степени, достаточной для создания снопообразного разряда и таким образом стать источником воспламенения взрывоопасных смесей. Снопообразные электростатические разряды это разряды из небольших поверхностей - литература и стандарты определяют эффективную площадь поверхности 100 см². Все трубы были тестированы максимально один метр от начала трубы. Сведений о величине электростатического заряда, например, в середине трубы не определено. Результаты: На основании проведенного тестирования можно констатировать, что:

1. Пластиковая труба является электростатическим диэлектриком и имеет очень хорошую способность электризации и накопления избыточного электрического заряда.

2. Труба не может разряжаться на заземленный проводник в случае контакта с заземлением.

3. Вся металлическая структура является электропроводной и соединена с заземлением, поэтому она не способна наэлектризоваться посредством электростатической индукции.

4. Сигнальные металлические провода, вставленные в пластиковые трубы, после подключения к тестируемой конструкции являются заземленным объектом с электрическим потенциалом равным нулю, так что электростатический разряд на металлическую проволоку весьма правдоподобен.

5. Пластиковая труба с очень большой внутренней поверхностью имеет множество эффективных поверхностей на площади 100 см², на которых накопленный электростатический заряд может инициировать проскакивание искры.

Выводы: Выводы этой работы позволяют определить меры по устранению опасности электростатического разряда и возгорания. Предлагаемые меры должны быть классифицированы по следующим группам:

- устранение электростатического разряда в качестве источника.

- устранение потенциально взрывоопасной атмосферы,

- недопущение возможности электростатического разряда.

Ключевые слова: статическое электричество, трубы, взрывоопасная атмосфера, способность к электризации

Вид статьи: оригинальная научная статья

Принята: 18.01.2016; Рецензирована: 18.03.2017; Опубликована: 31.03.2017;

Процентное соотношение участия в подготовке статьи: P. Kędzierski - 70\%, A. Szopa - 30\%;

Просим ссылаться на статью следующим образом: BiTP Vol. 45 Issue 1, 2017, pp. 14-25, doi: 10.12845/bitp.45.1.2017.1;

Настоящая статья находится в открытом доступе и распространяется в соответствии с лицензией CC BY-NC-SA 4.0

(https://creativecommons.org/licenses/by-nc-sa/4.0/). 


\section{Introduction, research objective}

An electrostatic discharge in a potentially explosive atmosphere can result in ignition. One of the methods for eliminating this possibility is to prevent the occurrence of an explosive atmosphere. The second method involves eliminating the possibility of electrostatic discharge formation. IEC 60079-32-1 [1] and CLC/TR 50404 [2] cite inerting as a means of eliminating an explosive atmosphere. Inerting has been included in publications presenting analyses of methods for the risk elimination of electrostatic discharge initiated explosions.

The aim of the study was to determine the electrostatic characteristics of plastic pipes in relation to the possibility of

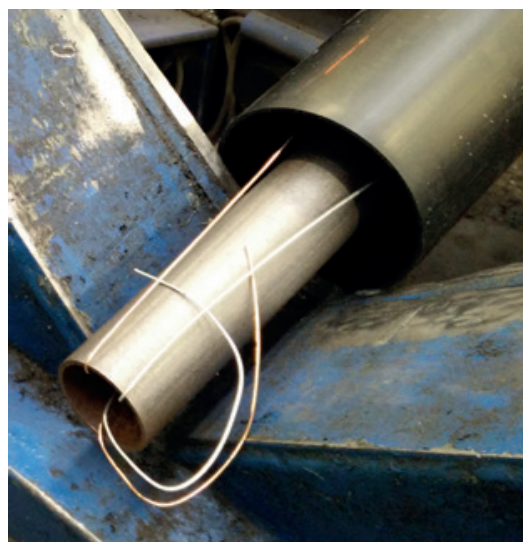

Figure 1a. Manufactured pre-insulated pipes

Source: Own elaboration.

The study was carried out at the manufacturer's production plants.

The manufactured pre-insulated pipes (Fig. 1a and 1b) consist of a metal pipe on the inside and a polypropylene pipe on the outside. The space between them is filled with a special foam which produces pentane (an explosive mixture with oxygen) during its formation. An explosion of the pentane mixture can be initiated by an electrostatic discharge's forming in the plastic pipes. The process of inertization, i.e. replacing oxygen with nitrogen, can be used to eliminate the possibility of explosion. This article addresses questions regarding the risks of electrostatic discharge formation and the ways to eliminate the possibility of their formation.
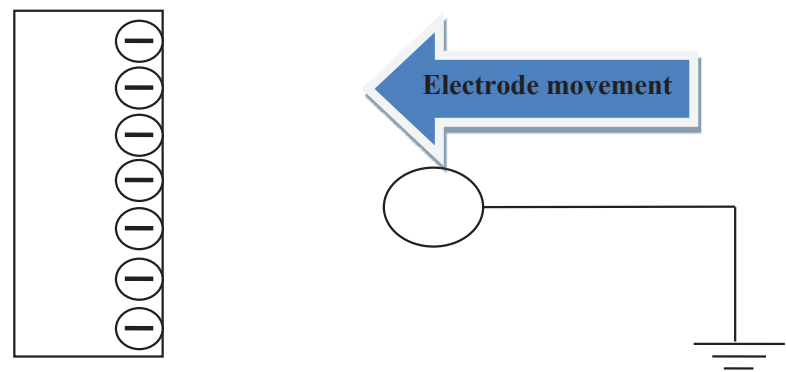

Figure 2. Typical brush discharge occurrence conditions (scheme)

Source: Own elaboration. occurrence of electrostatic discharge. This is to be determined with reference to safety, concerning the risk of explosion initiated by an electrostatic discharge forming on the electrified internal surface of a pipe.

The subject of this research was polyethylene pipes employed in the manufacturing of pre-insulated pipes. All pipes were made of polyethylene (the same production process covers several diameters of pipes). The pipes are used for heat transmission in district heating systems. They are made of polyethylene, which is a very good electric insulator. Polyethylene pipes comprise the casing and structure of the entire pre-insulated pipe. Heat transmission takes place in the metal pipe (see Figs. 1a and 1b).

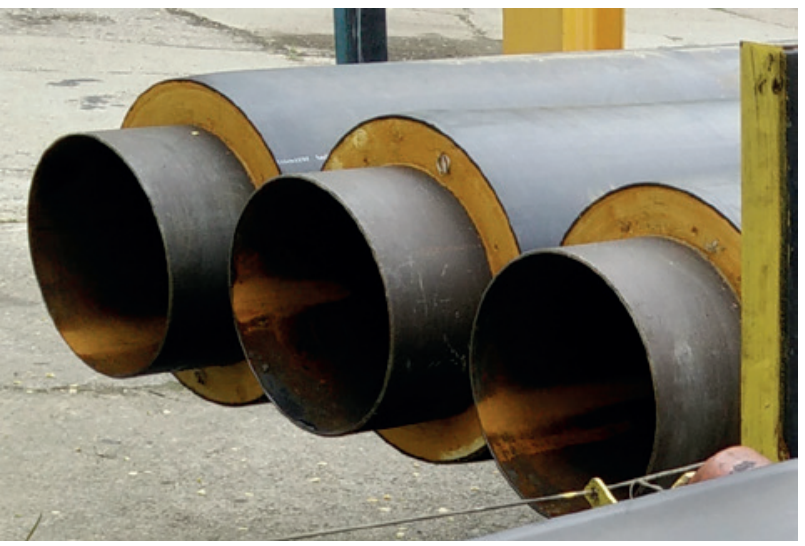

Figure 1b. Manufactured pre-insulated pipes

Source: Own elaboration

Accidents during the polyethylene pipe production process are known to happen, as the process can lead to ignition. The reason for this ignition is electrostatic discharges from charged pipes to metal elements, persons or instruments (grounded or in contact with the ground). An example of such a discharge is presented in Fig. 2, which shows a grounded electrode (representing a metal element, person or instrument) being moved closer to a charged element (the pipe).

A potential electrostatic discharge (Fig. 2) can occur:

- from an electrified polyethylene pipe to a grounded inserted metal pipe (Fig. 3),

- from an electrified polyethylene pipe to grounded non-insulated metal wires (Fig. 4).

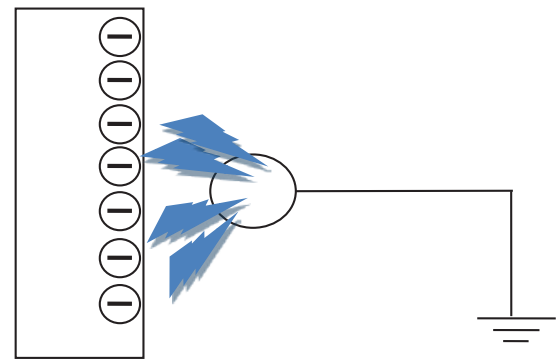




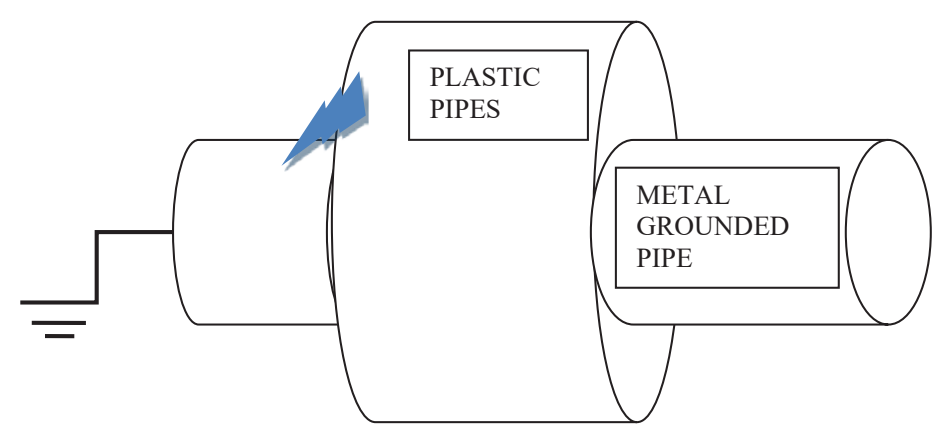

Figure 3. Discharge from an electrified polyethylene pipe to a grounded inserted metal pipe Source: Own elaboration.

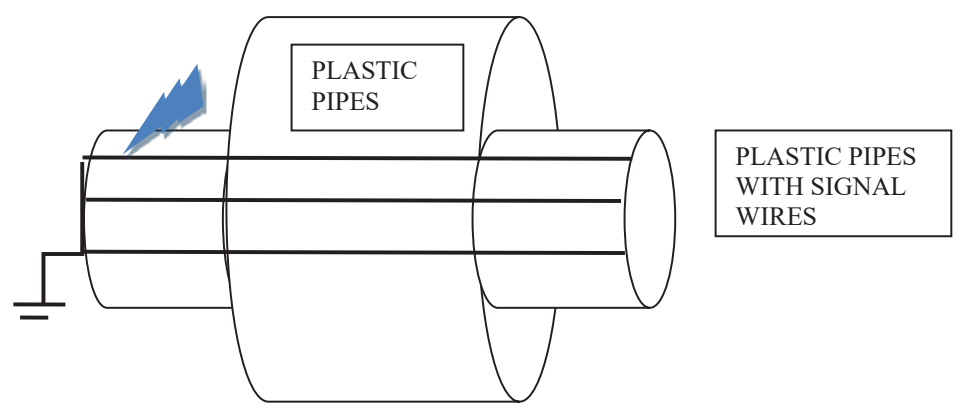

Figure 4. Discharge from an electrified polyethylene pipe to grounded non-insulated metal wires Source: Own elaboration.

An electrostatic discharge from an electrified polyethylene pipe will occur neither when a metal pipe is insulated from the ground nor when the signal wires are insulated. In this case, it will result in an electrostatic induction of the conducting pipe. Figure 2 also represents a schematic diagram of an electrification ability test (see section 3.3).

Based on the performed measurements of the electric potential and the electric charge field potential accumulated on the pipe, and on the basis of the transferred charge measurement carried out via a controlled discharge (spark or corona), it can be concluded that an electrostatic discharge hazard exists on the pipes. No hazard was found on the pipe fittings. In the case of an electrostatic discharge occurrence in a potentially explosive atmosphere, it can result in the ignition of the mixture.

\section{The principles of the phenomenon}

An electrostatic discharge is the phenomenon of transferring electric (electrostatic) charges between objects with different electric potentials as a result of direct contact. Most frequently, the discharge takes place between positively or negatively charged objects, or between an electrified object (with a high electric potential) and the ground (with zero-value electric potential). Electrostatic discharges are short pulses appearing in the spaces between objects with sufficiently high electrostatic potential differences. These result in either the partial or total decay of the electrostatic charge on these objects [5]. Since the duration of a discharge is relatively short, from several dozen nanoseconds to several hundred microseconds, the result is the formation of high power impulses, sufficient to ignite explosive atmospheres, cause electric shock to workers, and damage equipment. Electrostatic hazards are understood as the possibility of the occurrence of the aforementioned electrostatic discharge effects. Except for the electric shock, electrostatic discharges can be life-threatening only indirectly. Electrostatic hazards can be divided into three groups [7]:

- electrostatic shock occurrence possibility, i.e. an electrostatic discharge passing directly through the human body;

- flammable and explosive media ignition ability, resulting in a fire or explosion;

- operation interference or damage possibility of semiconductor devices constituting the elements of the control and measuring equipment, which controls the safe operation of technological processes, or diagnostics or live-support apparatus.

In electrostatics, materials are divided into three groups (Fig. 5): conductive, dissipative and insulating. Conductive and dissipative materials are considered anti-electrostatic, while insulators are considered non-anti-electrostatic.

There are two criteria: resistance (symbol $R$, expressed in $\Omega$ ) and resistivity (symbol $\rho$, expressed in $\Omega$ and $\Omega / m$ ). Resistance is the relationship between measurement voltage and current, while resistivity is the ability of materials to dissipative charging. In practice, resistivity is the ratio of the resistance and size of materials, and refers to unit length and is more universal than resistance, which is a test result. Resistance and resistivity can be surface and volume. It defines the direction of electrostatic-charge flow. 


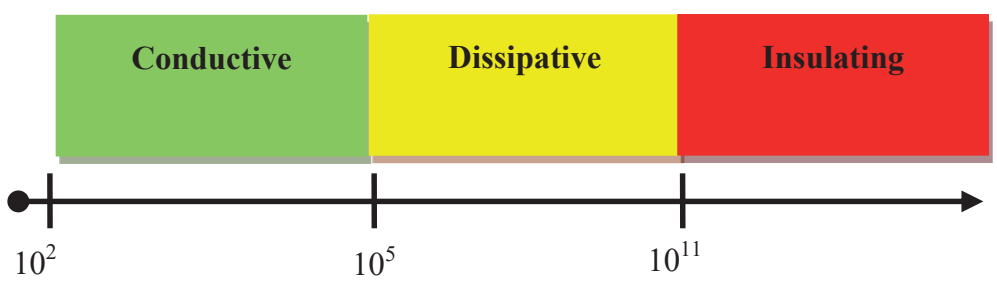

Figure 5. The division of materials in terms of electrostatic properties

Source: Own elaboration.

Moreover, the literature provides an additional division of materials into poorly electrifying, with a surface resistivity of $10^{9} \Omega<\rho_{s}<10^{12} \Omega$, and easily electrifying, with a surface resistivity of $\rho_{s}>10^{12} \Omega$. Solid materials with a volume resistivity of $\rho_{\mathrm{S}}>10^{8} \Omega \mathrm{m}$ are considered by the literature as objects prone to permanent electrification [3].

The PN EN 80079-36 [15] standard also defines the electrification ability test, aimed at determining the maximum safe magnitude of an electrostatic charge which might accumulate on a material. This safe charge value amounts to $60 \cdot 10^{-9} \mathrm{C}$. The electrification ability test is performed when a material does not fulfil the surface resistance criterion, i.e. its surface resistance is $R_{s}>10^{9} \Omega$.

\section{Electrification (electrostatic charging) ability}

Most materials have the ability to accumulate electric charges. When analysing electrification ability, one should consider the triboelectric series (Fig. 6.), i.e. an arrangement of materials in relation to their polarity and electric charge magnitude produced using contact and frictional methods. Some materials lose electrons more easily, while others accumulate them more easily.

\section{POSITIVE CHARGE}

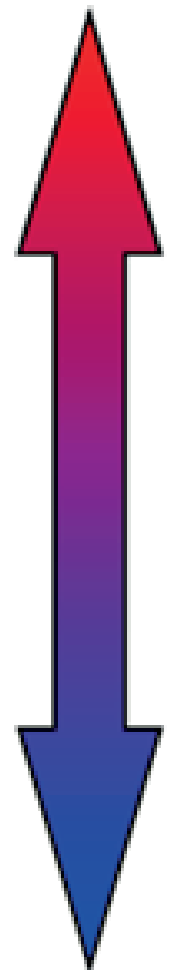

Human body

Glass

Mica

Polyamide

Wool

Fur

Silk

Aluminium

Paper

Cotton

Steel

Wood

Ebonite

Polyester

Polyethylene

PVC

PTFE

\section{NEGATIVE CHARGE}

Figure 6. The triboelectric series

Source: Own elaboration based on [5, p. 66] 


\section{Electrification (electrostatic charging) methods}

The literature mentions three electrification (electrostatic charging) methods. The triboelectric series in Fig. 6 is applicable only to contact and frictional methods.

\section{Through contact (including impact)}

Electrification through contact takes place at the moment when two materials come into contact and separate. During separation, in line with the triboelectric series rule, and depending on the character of the electron affinity, the materials give away or retain extra electrons. Thus, an electric imbalance takes place in the materials, i.e. a surplus of electrons in one of them, and a deficit in the other. An example of this can be seen when the feet are lifted from the ground (Fig. 7.), or when a plastic-covered book is opened.

At manufacturers' production plants, polyethylene pipes are electrified through contact when striking other pipes, falling off a conveyor, or rolling.

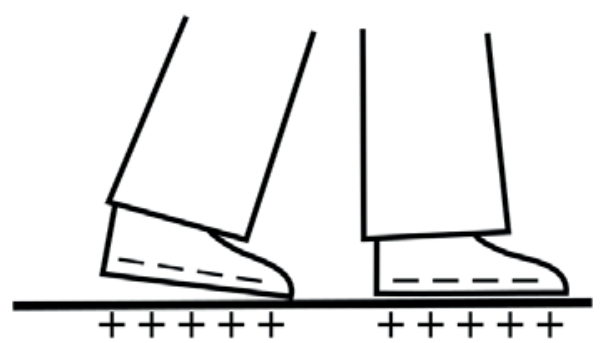

Figure 7. An example of electrification through contact - lifting the feet from the ground

Source: Own elaboration.

\section{Through friction}

Electrification through friction, like through contact, is related to the triboelectric series. As a result of friction, electric charges are transferred between the bodies, which results in charging with a surplus electric charge.

At manufacturers' production plants, polyethylene pipes are electrified through friction either during the course of the production process or during transportation.

\section{Through induction}

Electrification through induction, as opposed to contact and frictional methods, is a non-contact method of charging. Electrification through induction is often called electrification through influence. Only electricity-conducting materials can be electrified through induction, i.e. good electric conductors and dissipative materials. The electrified object is capable of electrifying another one through induction by creating a dipole on it. This is achieved via the separation of electric charges: single-sign charges are repulsive, while opposite-sign charges are attractive. Examples of electrification through induction are presented in Fig. 8. The electrified objects induce dipoles on conducting materials (cubes, the human body) [4]. Owing to the grounding and the carrying of a single-sign charge away from the material's acting as a dipole, the conductor becomes electrified with single-sign electricity.

At manufacturers' production plants, metal pipes inserted into polyethylene pipes are electrified through induction. A dipole is created on the metal pipe, and the electrons accumulated on one of the metal pipe surfaces are carried to the grounding system via an effectively grounded arm which inserts the inner metal pipe into the outer plastic one.

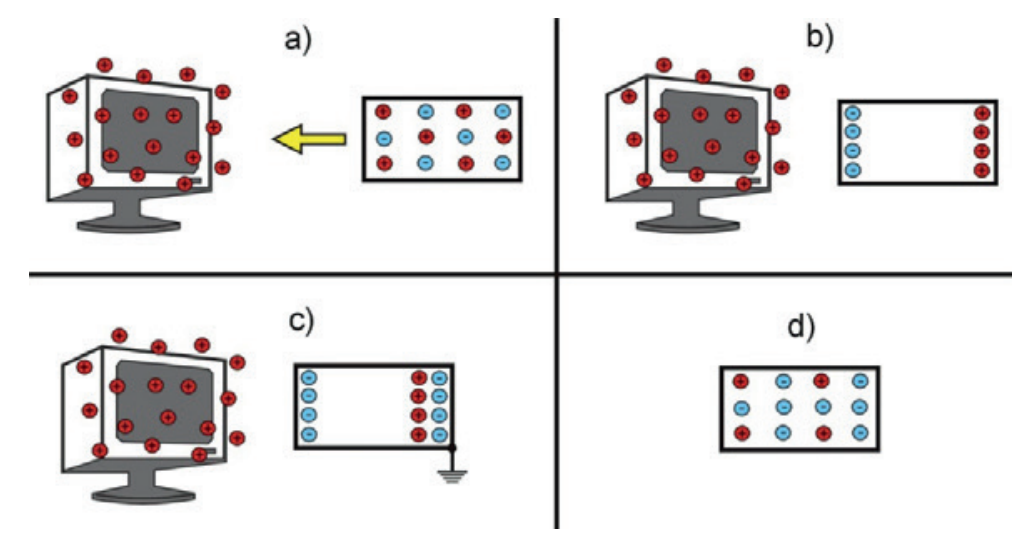

Figure 8. Electrification through induction

Phase a: An electrically neutral body inserted into an electric field

Phase b: The field causes the separation of the charges (polarisation)

Phase c: A negative charge is induced into the element after grounding, balancing the positive charge

Phase $d$ : The conductor is still negatively charged after the removal of the electric-field source

Source: Own elaboration. 


\section{Electrostatic discharges}

There are four main types of electrostatic discharges [3]:

1. Capacitive spark discharges, which ignite all explosive atmospheres.

2. Propagating brush discharges, which ignite all explosive atmospheres.

3. Brush discharges, which ignite all gassy atmospheres, but not dusty ones, except those containing initiator dusts.

4. Corona discharges, which are very low energy discharges, less than $0.1 \mathrm{~mJ}$. They are considered to be capable of igniting the most sensitive atmospheres, with ignition energy lower than $0.1 \mathrm{~mJ}$, or atmospheres with an elevated oxygen concentration.

Electrostatic discharges occur as a result of a high potential difference. The breakdown voltage of air is ca. $32 \mathrm{kV} / \mathrm{m}$, hence an electrostatic discharge will occur when the potential difference between the bodies exceeds the breakdown voltage of air. In most cases, such discharges are observed between an electrified object and one with zero potential (e.g. the ground). A discharge will not happen when an object is highly electrified, but there exists no potential difference between this and the other object.

\section{Ignition energy}

An explosive atmosphere is defined as a mixture of air with flammable substances in the form of gases, vapours, mists or dusts, under atmospheric conditions, in which combustion spreads to the entire unburned mixture after ignition (in accordance with Directive 2014/34/EU) [12]. The following types of atmospheres can be distinguished: dusty, gassy (flammable gases or vapours of flammable substances, typically liquids) and hybrids, i.e. mixtures of gassy and dusty atmospheres (e.g. methane and coal dust).

The minimum discharge energy necessary to ignite an explosive atmosphere is called the minimum ignition energy. It is determined as the minimum energy accumulated in the electric capacitance of a standard capacitor at which a spark discharge from the capacitor, under the proper electrode configuration, results in the ignition of the atmosphere [8]. An electrostatic discharge is considered as a process of rapid electrification decay, accompanied by a release of energy, together with light and acoustic effects. A brush discharge occurs in an electric field with high heterogeneity [9], when a grounded object of spherical shape and small curvature approaches the surface of an electrified dielectric. The brush discharge, accompanied by a light effect, has a form intermediately between corona and spark discharges. Its energy attains a level of ca. $4 \mathrm{~mJ}$.

Brush discharges are capable of initiating explosions of vapour or flammable gas mixtures with air, but they cannot initiate an explosion of a dust-air mixture. In the literature, according to both Polish and foreign standards, a brush discharge is considered dangerous only when the released charge originates from a surface greater than ca. $100 \mathrm{~cm}^{2}$ and electrified with a negative potential of at least $20 \mathrm{kV}$. In the document published by the Central Safety Committee [13], a brush discharge has been cited as an air mixture discharge initiator with an MIE ranging from 0.01 to $10 \mathrm{~mJ}$.

The potential energy of an electrostatic field is described with the following relationship:

$$
W=\frac{1}{2} C U_{0}^{2}=\frac{1}{2} Q_{0} U_{0}=\frac{1}{2} \frac{Q_{0}^{2}}{C}
$$

The following should be defined to describe potential energy: system electric capacitance $C$, electric potential, i.e. electrostatic voltage $\mathrm{U}$, and electric charge magnitude $\mathrm{Q}$.

\section{Research methodology}

\section{Resistance measurements}

Resistance measurement results and/or resistivity parameters, determined on the basis of the measured resistance, are used to determine the electrostatic properties of materials, i.e. to classify a material as conductive, dissipative or insulating.

Resistance measurement results differ depending on the employed test method (i.e. electrode configuration and measuring voltage). The resistance parameter is dependent on the condition that the test method has been specified.

Surface resistance is the electric resistance (in $\Omega$ ) between electrodes placed coaxially on the same surface of the tested object. Volume resistance is the electric resistance (in $\Omega$ ) between electrodes placed coaxially on opposite sides of the object. Surface resistivity is the capability of the material to reduce the current flow on its surface. Volume resistivity is the capability of the material to reduce the current flow through its volume [6].

Normalised test methods define the method for measuring surface and volume resistances. There are no equally common and universal parameters to define electrostatic properties. Most standards which define a resistance measurement method also specify the method of converting the measured resistance values into resistivity.

Further normalised resistance measurement methods include measurement between points, and measurement between a point and a ground point. This means the electric resistance (in $\Omega$ ) between electrodes (or an electrode and a grounding point) placed on the same surface at a considerable distance from each other.

The surface, volume, between points, and point-to-grounding resistance tests are conducted within the $A B 005$ accreditation framework and constitute normalised testing.

\section{Electrostatic field intensity and potential measurements}

Electrostatic field parameter measurements are performed by means of a portable electrostatic field meter, the so-called field mill meter. The device measures the electrostatic field intensity (in V/m), which can be automatically converted into the electric potential (in V). The measuring range of the Central Mining Institute's device ranges from $0 \mathrm{~V}$ to $160 \mathrm{kV}$, and from 0 to $800 \mathrm{kV} / \mathrm{m}$. All the measurements are performed relative to the ground, as the measuring device is grounded. The test is not standardised [11]. Electrostatic potential is connected with the potential energy of ignition (relationship in point 2.4). 


\section{Electrification ability measurement}

The electrification ability test (also called the electrification test) is a method for determining whether a non-conducting material is capable of charging to a level sufficient to result in a brush discharge, and thereby whether it can become an explosive mixture ignition source (see Figure 2, 3 and 4). The test involves the measurement of an electric charge $Q$ of a typical surface discharge leading to a controlled electric discharge. It is performed by using a spherical electrode to discharge a sample to a capacitor with a known electric capacitance $\mathrm{C}$ and measuring the voltage on its surface. The voltage measurement is conducted by means of an electrostatic voltmeter. The transferred charge is connected with the potential energy of ignition (the relationship in point 2.4).

\section{Test results and their discussion}

The electrostatic property tests were performed by the Group of Testing and Calibration Laboratories of the Central
Mining Institute, with the accreditation of the Polish Accreditation Centre; certificate No. AB005. The test results were included in test reports, and in Tables 1, 2, 3 and 4. The manufactured pipes varied in terms of dimension (diameter). The pipes marked as type 3 were the most numerously manufactured and the most available in stock. Pipe diameter is not connected with ignition possibility, because, according to $\mathrm{CLC} / \mathrm{TR} 50404$ [2], the effective ignition generation surface is always $100 \mathrm{~cm}^{2}$. All tests (excluding the testing of electrostatic field intensity) were performed according to the methods shown in [1]. A normalised method of testing is a guarantee that the results will be correct.

The surface resistance of the material determines this material as one of the three from Fig. 5 . This plastic is classified as an insulator. It means that this plastic can easy accumulate a charge. The results and their low uncertainty indicate the homogeneity of the raw materials and produced pipes.

Table 1. The surface resistances of pipes

\begin{tabular}{|c|c|}
\hline Measurement point/object & Surface resistance $[\Omega]$ \\
\hline Pipe 1 & $7.45 \cdot 10^{11}$ \\
\hline Pipe 2 & $8.54 \cdot 10^{11}$ \\
\hline Pipe 3 & $6.51 \cdot 10^{11}$ \\
\hline Pipe 4 & $7.12 \cdot 10^{11}$ \\
\hline Pipe 5 & $6.66 \cdot 10^{11}$ \\
\hline Arithmetic mean & $7.26 \cdot 10^{11}$ \\
\hline Uncertainty & $1.53 \cdot 10^{11}$ \\
\hline MIN value & $6.51 \cdot 10^{11}$ \\
\hline MAX value & $8.54 \cdot 10^{11}$ \\
\hline
\end{tabular}

Source: Own elaboration.

Table 2. Transferred electric charge

\begin{tabular}{|c|c|c|c|}
\hline \multicolumn{3}{|c|}{ Transferred charge [nC] } & \multirow{2}{*}{$\begin{array}{c}\text { Measurement point } \\
1 \\
\end{array}$} \\
\hline 1361.4 & \pm & 28.1 & \\
\hline 48.3 & \pm & 1.0 & 2 \\
\hline 57.9 & \pm & 1.2 & 3 \\
\hline 67.6 & \pm & 1.4 & 4 \\
\hline 57.9 & \pm & 1.2 & 5 \\
\hline 77.2 & \pm & 1.6 & 6 \\
\hline 96.6 & \pm & 2.0 & 7 \\
\hline 270.3 & \pm & 5.6 & 8 \\
\hline 144.8 & \pm & 3.0 & 9 \\
\hline 96.6 & \pm & 2.0 & 10 \\
\hline 29.0 & \pm & 0.6 & 11 \\
\hline 77.2 & \pm & 1.6 & 12 \\
\hline 154.5 & \pm & 3.2 & 13 \\
\hline 9.7 & \pm & 0.2 & 14 \\
\hline
\end{tabular}

Source: Own elaboration.

The transferred electric charge (simulated electrostatic discharge) was measured to determine the maximum electric charge magnitude capable of initiating explosions. The transferred charge (in Table 2) was always collected from the same area (size of area). The measurement point was random and covered the whole pipe. In order to estimate the test results, the maximum scores were 
subjected to a series of 10 measurements. The test results do not depend on the pipe diameter. The results depend only on the pipe's electrification type, method and level during manufacture. The test results in Table 2 are the results of simulated discharge. Some results are much higher than others, possibly due to the longer process of transport (multiple exposure to the electrisation process through contact, friction and induction).
The same problem exists in the measurement of electrostatic potential and electrostatic field. The measurement point was random and covered the whole pipe. In order to estimate the test results, the maximum scores were subjected to a series of 10 measurements. Pipes are insulators and they have the ability to become electrified during transportation, the production process etc. Values in Table 3 are the maximum values in pipes.

Table 3. Electrostatic field intensity and potential

\begin{tabular}{|c|c|c|}
\hline Measurement point & Electrostatic potential [V] & Electrostatic field [V/m] \\
\hline 1 & 143,000 & 36,000 \\
\hline 2 & 170,000 & 102,000 \\
\hline 3 & 300,000 & 9,200 \\
\hline 4 & 240,000 & 36,000 \\
\hline 5 & 98,000 & 33,000 \\
\hline 6 & 2,600 & 133,000 \\
\hline 7 & 1,760 & 195,000 \\
\hline 8 & 2,780 & 320,000 \\
\hline 9 & 7,500 & 280,000 \\
\hline 10 & 6,200 & 440,000 \\
\hline 11 & 5,120 & 412,000 \\
\hline 12 & 4,400 & 333,000 \\
\hline 13 & 4,120 & 299,000 \\
\hline 14 & 7,600 & 411,000 \\
\hline 15 & 6,080 & 390,000 \\
\hline 16 & 2,000 & 181,000 \\
\hline 17 & 6,000 & 168,000 \\
\hline 18 & 4,000 & 332,000 \\
\hline
\end{tabular}

Source: Own elaboration

The pipes were transported from the production hall to the depot. This transportation was made using metal structures with conveyor belts. The transport system wasn't antistatic - this fact determines the ability to charge during transportation and the impossibility to decay an accumulated charge.

Table 4. The ground resistance of pipe transportation structures

\begin{tabular}{|c|c|}
\hline Measurement point & Resistance point to ground RGP $[\Omega]$ \\
\hline & $1.20 \cdot 10^{3}$ \\
\hline \multirow[t]{2}{*}{ Ending } & $1.20 \cdot 10^{3}$ \\
\hline & $1.00 \cdot 10^{3}$ \\
\hline \multirow{3}{*}{ Conductor without isolation } & $1.10 \cdot 10^{3}$ \\
\hline & $1.00 \cdot 10^{3}$ \\
\hline & $1.00 \cdot 10^{3}$ \\
\hline \multirow{3}{*}{ Conductor with isolation } & $>1.00 \cdot 10^{12}$ \\
\hline & $>1.00 \cdot 10^{12}$ \\
\hline & $>1.00 \cdot 10^{12}$ \\
\hline \multirow{3}{*}{ Structure point 1} & $1.00 \cdot 10^{3}$ \\
\hline & $1.00 \cdot 10^{3}$ \\
\hline & $1.00 \cdot 10^{3}$ \\
\hline \multirow{3}{*}{ Structure point 2} & $1.00 \cdot 10^{3}$ \\
\hline & $1.00 \cdot 10^{3}$ \\
\hline & $1.00 \cdot 10^{3}$ \\
\hline
\end{tabular}

Source: Own elaboration. 
The ground resistance of pipe transportation structures was measured to determine the capability of spark-over to the ground, and to employ grounding as a neutralisation method for plastic pipes. The test results showed no connection to ground the pipes. The pipes cannot be discharged because there is no access to the ground.

On the basis of the performed tests (the results in Tables 1 , 2, 3 and 4), the following conclusions can be drawn:

- The polyethylene pipe is an electrostatic insulator. It has very good electrification and surplus electric charge accumulation abilities. The pipe is not capable of carrying the charge to the ground when in contact with the grounding system.

- The entire metal structure is conductive and connected to the ground; hence it is not capable of electrification through induction. Signal-transmitting wires inserted into the plastic pipes constitute a grounded object with an electric potential equal to zero, due to their connection to the studied structure. Therefore, a discharge into the metal wire is very likely.

- An electrostatic discharge from the pipe surface into the insulated signal wires is not possible, since their ground resistance is very high. In consequence, from the point of view of an electric circuit, they constitute a gap.

- The electrostatic charge accumulated on the pipe is relatively large, with a high potential. The potential should be considered as the voltage difference in the pipe/non-insulated metal wire system, as the potential of the metal wire equals zero (see above). In many cases, the electrostatic charge potential on the pipes, and consequently the electric voltage, exceeds the breakdown voltage of air. A large electrostatic charge is not observed on the pipe fittings.

- An electrification ability test was performed, which gives sufficient information regarding whether a non-conducting material can be electrified to a degree sufficient to result in an electric-brush discharge. The pipes were tested at no further than one metre from the mouth of the pipe. Information regarding the magnitude of the electric charge, for instance, in the middle of a pipe, is not available. Electrostatic brush discharges are discharges from small surfaces. The literature and standards consider $100 \mathrm{~cm}^{2}$ to be an effective surface area. A polyethylene pipe with a very large internal surface area has many effective $100 \mathrm{~cm}^{2}$ surface areas from which the accumulated charge can initiate a spark-over.

\section{Test conclusions}

According to the "Pentane Process Technology. Safety Conception" documentation presented by the manufacturer, pentane is produced over the course of the pipe-manufacturing process during foaming. When mixed with air, pentane also creates an explosive mixture. According to the characteristics charts of the Central Institute of Labour Protection - National Research
Institute [14], the minimum ignition energy of a pentane-oxygen mixture equals $0.18 \mathrm{~mJ}$, and is lower than the minimum methane ignition energy, which ranges from $0.28 \mathrm{~mJ}$ to $0.47 \mathrm{~mJ}$.

In standards [1] and [2] and papers [10] and [11] there are criteria of conformity assessment: a surface resistance less than $1 \times 10^{9} \Omega$ or a transferred charge during a charge ability test less than $60 \cdot 10^{-9}$. The test results, shown in this paper do not fulfil the criteria of Polish and European standards for potentially explosive atmospheres.

On the basis of laboratory tests of a pipe taken from the production batch, it can be concluded that it is a very good quality insulator, with surface and volume resistances over $1 \cdot 10^{11} \Omega$. This means that the product can become electrified to a great extent. In the case of objects made of non-conducting materials, such as the considered pipe, there is a possibility of brush discharge. In exceptional cases, a propagating brush discharge can occur. Electrostatic discharges are able to ignite all types of explosive mixtures.

Based on the tests performed on the manufacturer's premises, it was found that the metal pipe insertion station was very effectively grounded; its electrostatic potential was close to zero. It was also found that the signal-transmitting wires placed on the inserted metal pipes were very effectively grounded and they carried away the electric charge. This relates only to non-insulated metal wires, which are grounded through metal weights and through contact with the production station.

\section{Conclusions regarding the elimination of electrostatic charge and ignition possibility}

Ignition possibility can be eliminated through three actions:

- Removing discharge sources in the form of electrostatic charges,

- Eliminating potentially explosive atmospheres,

- Preventing the possibility of electrostatic discharge formation.

All the three factors identified in the preventive measures listed above must take place at the same time for an explosion hazard to appear. Removing one of them will eliminate the hazard [10]. Apart from these three (which constitute the scope of the research), one should also take others into account, i.e. the explosive mixture concentration, the explosive atmosphere MIE, pressure, temperature, etc. To eliminate the ignition possibility, one of the factors contributing to ignition needs to be eliminated. This can be achieved by employing one of the listed actions.

The proposed preventive measures apply chiefly to pipes.

- Using insulated wires and insulating the inserted metal pipe (preventing the possibility of electrostatic discharge formation)

Using only wires with insulation and insulating the inserted metal pipe from the pusher will prevent the electrostatic charge accumulated on the propylene pipe's becoming neutralised by the wire. This means that a discharge will not occur, since, from the electrical point of view, the insulated wire constitutes a gap. 
- Increasing the relative air humidity (removing discharge sources in the form of electrostatic charges)

The literature and personal research reveal that the relative air humidity effectively neutralises the surplus electrostatic charge; not to zero, but to a safe level. Maintaining the relative humidity at a level of ca. $60 \% \mathrm{RH}$ is sufficient for high electrostatic charge potential neutralisation.

- The further inertisation process (eliminating potentially explosive atmospheres)

The aim of the inertisation process is to remove a potentially explosive atmosphere. The volume of nitrogen pumped into the pipe must be equal to or greater than the volume limited by the pipe itself.

- The ventilation of pipes (eliminating potentially explosive atmospheres)

Ventilation can be applied to fittings, just as it is done now. Fittings are ventilated to eliminate explosive atmospheres.

- Applying at least one conductive signal wire guide, which will electrostatically neutralise the polyethylene pipe (removing discharge sources in the form of electrostatic charges)

The applied method has been simulated by the Central Mining Institute research team (Fig. 9.). The use of the first guide, made of conducting or anti-electrostatic plastics, results in the inserted metal pipe's neutralising the plastic pipe's entire internal surface. Afterwards, the electrostatic charge is carried to the ground through the pusher structure.

- The use of air ionisers (removing discharge sources in the form of electrostatic charges)

Ionisers effectively neutralise the surplus electrostatic charge. A restriction on this method is its time of neutralisation. The ioniser must blow in a volume of ionised air equal to the volume of the pipe for a sufficiently long time. Ionisers can be applied to blowing down fittings and joints.

The manufacturer uses a preventive measure in the form of inertisation, i.e. the removal of potentially explosive atmospheres, during its pipe production process. The use of any of the remaining preventive measures will result in the elimination of one of the three aforementioned explosion occurrence factors. Consequently, the chain of events necessary to provoke an explosion will be interrupted - the same chain of events necessary to provoke an explosion of an explosive atmosphere.

The use of insulated wires and the insulation of the pusher structure eliminates the possibility of an electrostatic discharge occurrence. Thus, subjecting this type of pipes to the inertisation process is unnecessary.

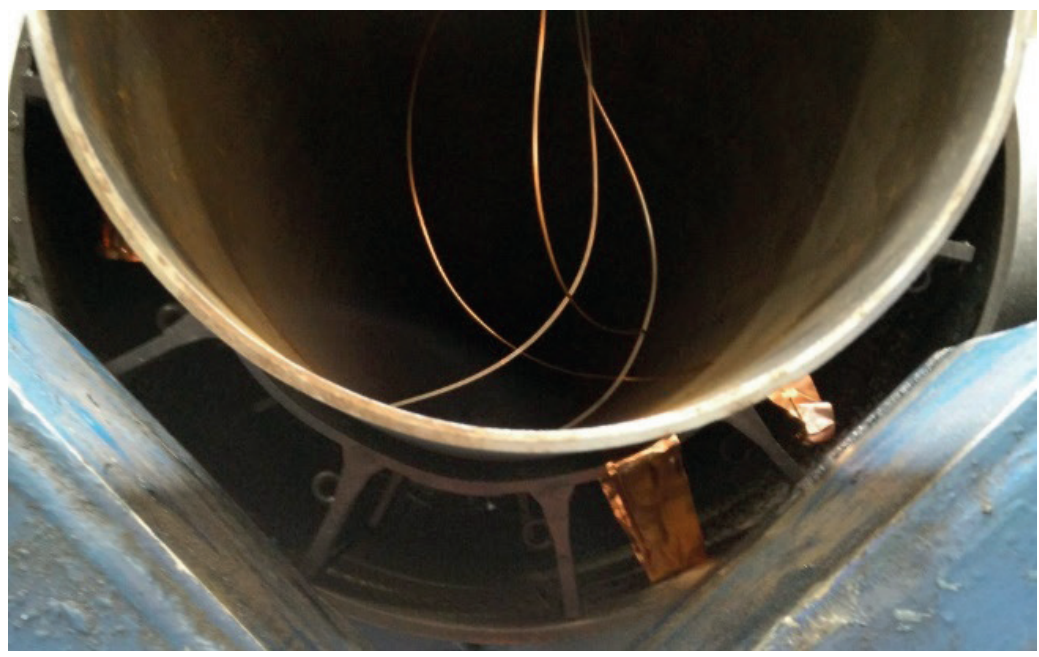

Figure 9. Signal wire guide on the metal pipe

Source: Own elaboration.

These three factors, which result in ignition via an electrostatic discharge, apply not only to pipes, but also to most types of plastics. Similarly, the proposed measures involve not only pipes, but also most types of plastics. The conclusions in section 6 can be applied in all situations in which electrostatic discharge-related hazards can exist.

\section{References}

[1] IEC TS 60079-32-1:2015-08, Technical Specification, Explosive atmospheres - Part 32-1: Electrostatic hazards, guidance.

[2] CLC/TR TR 50404:2003 Elektrostatyka - kodeks postepowania praktycznego dla uniknięcia zagrożeń związanych z elektrycznością statyczną.
[3] Gajewski J., Elektryczność statyczna - poznanie, pomiar, zapobieganie, eliminowanie, Instytut Wydawniczy Związków Zawodowych, Warszawa 1987

[4] Grabarczyk Z., Jonizacja powietrza w środowisku życia i pracy, CIOP, Warszawa 2000.

[5] Grabarczyk Z., Kurczewska A., Zagrożenia elektrostatyczne w strefach zagrożonych wybuchem, CIOP, Warszawa 2008.

[6] Kacprzyk R., Metody pomiarów w elektrostatyce, Politechnika Wrocławska, Wrocław 2013.

[7] Pawłowska Z. (red.), Podstawy prewencji wypadkowej, CIOP, Warszawa 2008.

[8] Świerżewski M., Urządzenia elektryczne w przestrzeniach zagrożonych wybuchem - zagadnienia wybrane, SEP, Warszawa 2008.

[9] Urządzenia do pracy w atmosferze zagrożonej wybuchem, Asco/ Joucomatic, Warszawa 2010. 
[10] Kędzierski P., Antystatyzacja w ujęciu technologicznym, „Wiadomości Górnicze" 2013, 12.

[11] Kędzierski P., Badania dynamicznych właściwości elektrostatycznych - metody symulacji wyładowań, „Wiadomości Górnicze” 2012, 6 .

[12] Directive 2014/34/EU Equipment for potentially explosive atmospheres (ATEX).

[13] Electrostatic discharge, Central Safety Committee, Basel 1974.

[14] Characteristics charts of pentane, CIOP.

[15] PN-EN 80079-36:2016-07 Atmosfery wybuchowe - Część 36: Urządzenia nieelektryczne do atmosfer wybuchowych - Metodyka i wymagania.
PRZEMYSŁAW KĘDZIERSKI, MSc.Eng. - researcher at the Central Mining Institute in Katowice. Graduate of the Faculty of Electrical Engineering and the Faculty of Organization and Management of the Silesian University of Technology. He has been admitted into a Ph.D. programme by the GIG Science Council. A head of many research and expert studies, as well as research works in the field of static electricity. He has professional qualifications of an ESD Coordinator.

ADAM SZOPA, M.Sc.Eng. - a graduate of Silesian University of Technology in Gliwice, Faculty of Mathematics and Physics in the field of Technical Physics, specialization - optoelectronics. An engineering and technical worker at the Laboratory of Technical Acoustics at the Central Mining Institute in Katowice. 